\author{
Research Article
}

\title{
Catalytic Hydrodeoxygenation of Fatty Acids for Biodiesel Production
}

\author{
Antonina A. Stepacheva ${ }^{1 *}$, Valentin N. Sapunov' ${ }^{2}$ Esther M. Sulman ${ }^{1}$, \\ Linda Zh. Nikoshvili ${ }^{1}$, Mikhail G. Sulman ${ }^{1}$, Alexander I. Sidorov ${ }^{1}$, Galina N. \\ Demidenko' $^{1}$, Valentina G. Matveeva ${ }^{1}$ \\ ${ }^{1}$ Tver Technical University, Department of Biotechnology and Chemistry, \\ A. Nikitina str., 22, Tver 170026, Russia \\ ${ }^{2}$ D. Mendeleyev University of Chemical Technology of Russia, Miusskaya sq. 9, \\ 125047 Moscow, Russia
}

Received: 31st July 2015; Revised: 9th December 2015; Accepted: 30th December 2015

\begin{abstract}
This paper is devoted to the production of second generation biodiesel via catalytic hydrodeoxygenation of fatty acids. $\mathrm{Pd} / \mathrm{C}$ catalysts with different metal loading were used. The palladium catalysts were characterized using low-temperature nitrogen physisorption and X-ray photoelectron spectroscopy. It was revealed that the most active and selective catalyst was $1 \%-\mathrm{Pd} / \mathrm{C}$ which allowed reaching up $97.5 \%$ of selectivity (regarding to $\mathrm{n}$-heptadecane) at $100 \%$ conversion of substrate. Moreover, the chosen catalyst is more preferable according to lower metal content that leads the decrease of the process cost. The analysis of the catalysts showed that $1 \%-\mathrm{Pd} / \mathrm{C}$ had the highest specific surface area compared with $5 \%$ $\mathrm{Pd} / \mathrm{C}$. Copyright (C) 2016 BCREC GROUP. All rights reserved
\end{abstract}

Keywords: Fatty Acids; Catalytic Hydrodeoxygenation; Palladium Catalyst; Biodiesel

How to Cite: Stepacheva, A.A., Sapunov, V.N., Sulman, E.M., Nikoshvili, L.Z., Sulman, M.G., Sidorov, A.I., Demidenko, G.N., Matveeva, V.G. (2016). Catalytic Hydrodeoxygenation of Fatty Acids for Biodiesel Production. Bulletin of Chemical Reaction Engineering \& Catalysis, 11 (2): 125-132 (doi:10.9767/bcrec.11.2.538.125-132)

Permalink/DOI: http://dx.doi.org/10.9767/bcrec.11.2.538.125-132

\section{Introduction}

At present the world power strongly depends on fossil resources (oil, coal and gas), the necessity in fossil fuels increases annually and their reserves decreases. Thus, the alternative renewable energy sources, which are able to provide stable long-term energy production, are of great importance [1].

* Corresponding Author.

E-mail: a.a.stepacheva@mail.ru (A. Stepacheva), Telp/Fax: +7-4822-789317
On experts forecasts the further decrease in manufacture of traditional energy sources is expected in the next decades. Hence, there is a necessity for reorganization of power balance for polypower development, i.e. the systems based on the use of several energy sources, any of which does not play defining role.

Renewable biofuels can be widely applied in various diesel engines. For example, at present the actual problem for railway transportation is the improvement of ecological indicators of diesel locomotives according to requirements of the international norms and standards. The analysis of the methods of estimation and ways of decrease in negative ecological influence of 
diesel engines on environment shows that now the basic direction is the use of alternative fuels [2]. Nowadays, the following types of biofuels are the most widely used ones: biogas, bioethanol, biodiesel, biobutanol [1].

Among the various fuels-from-biomass investigated, fatty acid methyl ester biofuels (FAME) obtained by transesterification of triglycerides (TG) from natural oils and fats with methanol have received considerable attention. They exhibit high cetane number and are considered to burn cleanly; however, there is growing concern about the comparability of these fuels with conventional petroleumderived diesel due to the oxidative and thermal instability. Reduction of the oxygen content in the fuel would readily improve the stability of the fuel and therefore its utilization potential [3].

It is noteworthy, that biodiesel of best quality should contain compounds with certain unsaturation degree, which is characterized by iodine number (optimum iodine number should not exceed $120 \mathrm{~g} \mathrm{I}_{2} / 100 \mathrm{~g}$ ). Biodiesel produced via transesterification of TG contains rather high level of unsaturated hydrocarbon chains in comparison with petrodiesel.

Various processes including hydrogenolysis, decarbonylation, and decarboxylation have been proposed to transform the biodiesel into the hydrocarbon based fuel [3]. The most promising way of biofuel obtaining in the form of saturated hydrocarbons with carbon number 15-22 is deoxygenation of fatty acids and their derivatives. The fuel produced by such method is called the second generation biodiesel or Green diesel.

Green diesel production process is conducted in mild conditions and is well integrated in the framework of existing oil refining factories. In contrast to FAME, where fuel properties depend of raw source and composition, Green diesel is the product which does not depend on raw materials origin, and is mixing easily with common diesel fuel. Comparison of fuel characteristics for diesel, biodiesel and Green diesel is presented in Table 1.

Presented data clearly shows that the second generation biodiesel has fuel characteristics similar to petroleum diesel. Thus for fuel manufacturers Green diesel is a preferable diesel component for the mixing as it has the boiling point interval comparable to typical diesel products, as well as significant high cetane number and low density [5].

Catalytic deoxygenation of fatty acids, obtained by hydrolysis of TG, and their alkyl es- ters is the new way of biodiesel production in the form of diesel-like hydrocarbons. Deoxygenation process is removing of oxygen of fatty acid carboxyl group with production of saturated or unsaturated hydrocarbons [6].

The deoxygenation of vegetable-based feeds is typically related to pyrolysis (cracking), where the hydrocarbon chain is broken. The drawback of this approach is the loss of carbon and decreasing energy content of the produced fuel.

There are several possible reaction paths for production of straight-chain hydrocarbons. Fatty acids can be directly decarboxylated or decarbonylated. Direct decarboxylation removes the carboxyl group by releasing carbon dioxide and producing a paraffinic hydrocarbon, while direct decarbonylation produces an olefinic hydrocarbon via removal of the carboxyl group by forming carbon monoxide and water, as illustrated by reactions (1) and (2).

$$
\begin{aligned}
& \mathrm{R}-\mathrm{COOH} \rightarrow \mathrm{R}-\mathrm{H}+\mathrm{CO}_{2} \\
& \mathrm{R}-\mathrm{COOH} \rightarrow \mathrm{R}-\mathrm{H}+\mathrm{CO}+\mathrm{H}_{2} \mathrm{O}
\end{aligned}
$$

Additionally, the fatty acid can be deoxygenated by adding hydrogen; in this case, the production of linear hydrocarbon can occur via direct hydrogenation or indirect decarbonylation, reactions (3) and (4), respectively.

$$
\begin{aligned}
& \mathrm{R}-\mathrm{COOH}+\mathrm{H}_{2} \rightarrow \mathrm{R}-\mathrm{CH}_{3}+\mathrm{H}_{2} \mathrm{O} \\
& \mathrm{R}-\mathrm{COOH}+\mathrm{H}_{2} \rightarrow \mathrm{R}-\mathrm{H}+\mathrm{CO}+\mathrm{H}
\end{aligned}
$$

Table 1. Comparison of main characteristics of diesel, biodiesel and Green diesel [4]

\begin{tabular}{lccc}
\hline \multicolumn{1}{c}{ Indicators } & $\begin{array}{c}\text { Petro- } \\
\text { leum } \\
\text { ULSD }\end{array}$ & $\begin{array}{c}\text { Biodiesel } \\
\text { (FAME) }\end{array}$ & $\begin{array}{c}\text { Green } \\
\text { diesel }\end{array}$ \\
\hline $\begin{array}{l}\text { Oxygen con- } \\
\text { tent, \% }\end{array}$ & 0 & 11 & 0 \\
$\begin{array}{l}\text { Specific gravity } \\
\text { Sulfur } \\
\text { content, ppm }\end{array}$ & 0.84 & 0.88 & 0.78 \\
$\begin{array}{l}\text { Heating } \\
\text { value, MJ/kg }\end{array}$ & $<10$ & $<1$ & $<1$ \\
Cloud point, oC & -5 & -5 to +15 & -30 to -10 \\
Cetane & 40 & $50-60$ & $70-90$ \\
$\begin{array}{l}\text { Lubricity } \\
\text { Stability }\end{array}$ & $\begin{array}{c}\text { Baseline } \\
\text { Baseline }\end{array}$ & $\begin{array}{c}\text { Good } \\
\text { Poor }\end{array}$ & $\begin{array}{c}\text { Baseline } \\
\text { Baseline }\end{array}$ \\
\hline
\end{tabular}


More than 80 years ago, Bertram succeeded to decarboxylate stearic acid to heptadecane by a homogeneous catalytic reaction over selenium. The paraffin yield of just 50\% was, however, obtained, and simultaneous dehydrogenation of produced paraffin to olefin was observed. Much later, Foglia and Barr demonstrated conversion of fatty acids to alkenes by a homogeneous catalytic reaction with complexes of palladium and rhodium.

The heterogeneous catalyzed deoxygenation of vegetable-based feeds has been studied scarcely in the past (with the exception of cracking). Decarboxylation of aliphatic and aromatic carboxylic acids was carried out in the gas phase over $\mathrm{Pd} / \mathrm{SiO}_{2}$ and $\mathrm{Ni} / \mathrm{Al}_{2} \mathrm{O}_{3}$. The experimental results showed that $\mathrm{Pd} / \mathrm{SiO}_{2}$ catalyst gave a much higher yield in decarboxylating heptanoic and octanoic acid (98\% and $97 \%$, respectively) than that achieved over the $\mathrm{Ni} / \mathrm{Al}_{2} \mathrm{O}_{3}$ catalyst ( $26 \%$ and $64 \%$, respectively). Production of straight-chain olefins from saturated fatty acids and fatty acid esters over a nickel based catalyst promoted with either tin, germanium, or lead was a subject of a patent [7].

The hydrodeoxygenation catalysts are often platinum group metals supported on inorganic carriers or carbon $\left(\mathrm{Pt} / \mathrm{C}, \mathrm{Pt} / \mathrm{Al}_{2} \mathrm{O}_{3}, \mathrm{Pd} / \mathrm{C}\right)$ [5-8]. The industrial catalysts are $\mathrm{CoMo} / \mathrm{Al}_{2} \mathrm{O}_{3}$ and $\mathrm{NiMo} / \mathrm{Al}_{2} \mathrm{O}_{3}$ ) [9], Zeolites [10,11] and composite

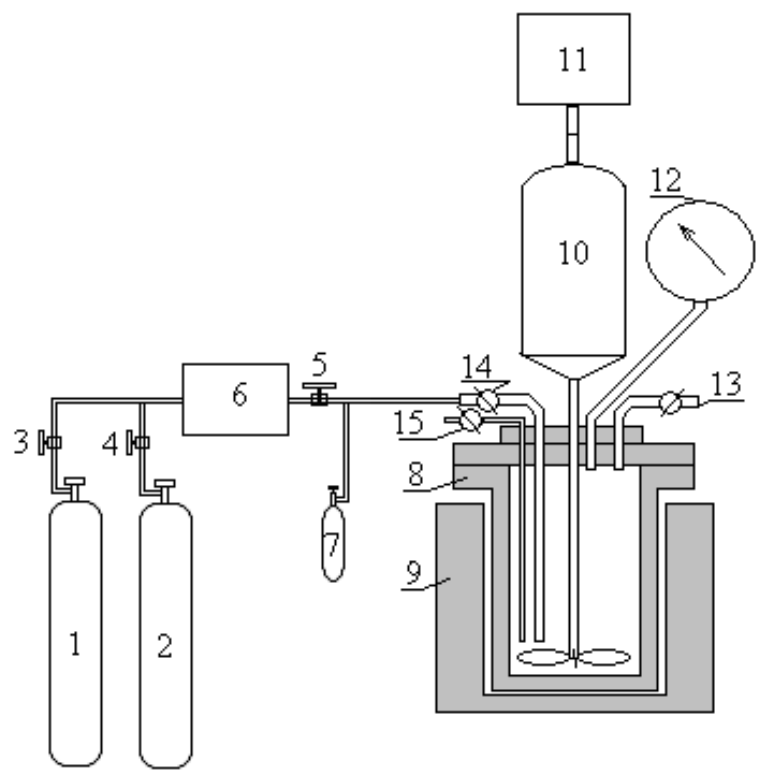

Figure 1. Scheme of hydrodeoxigenation reaction setup. 1, 2: hydrogen tanks, 3-5: valves; 6 : compressor; 7: buffer-tank; 8: reactor; 9: thermostat; 10: stirrer; 11: electric motor; 12 : manometer; 13-15: valves catalysts $\mathrm{Ni}-\mathrm{Cu} / \mathrm{CeO}_{2}-\mathrm{ZrO}_{2}$ were also explored [12]. These catalysts allow a substrate conversion of more than $90 \%$ but they lose catalytic activity because of the active metal leaching and the surface contamination. These considerable drawbacks make the development of new catalytic systems characterized by high activity and stability a vital task in the technology of Green-diesel production.

In this paper, we report on the physicochemical characterization of palladium catalysts and their catalytic properties in the reaction of fatty acid hydrodeoxigenation. As an example of fatty acids in this work stearin acid was used. Also the possible reaction pathways were proposed.

\section{Materials and Methods}

\subsection{Materials}

Stearic acid (KhimMedService, Tver, Russia) was used as raw material for the hydrodeoxygenation process. Two commercial catalysts (purchased from Sigma Aldrich) were used: $\mathrm{Pd} / \mathrm{C}$ (1\%(wt.) of $\mathrm{Pd}$ ) and $\mathrm{Pd} / \mathrm{C}$ (5\%(wt.) of $\mathrm{Pd}$ ).

\subsection{Experimentals}

Experimental setup for the hydrodeoxygenation process (see Figure 1) includes reactor (PARR-4307, volume $25 \mathrm{~mL}$ ), equipped with thermostat (accuracy $-0.5^{\circ} \mathrm{C}$ ), manometer and mechanical stirrer (maximum rate of mixing $700 \mathrm{rpm}$ ). Catalytic hydrodeoxigenation was conducted at temperature $255{ }^{\circ} \mathrm{C}$, hydrogen pressure 0.6 $\mathrm{MPa}$, during 280 minutes; $n$ dodecane was used as a solvent. Concentration of fatty acid solution (stearic acid) was 0.1 $\mathrm{mol} / \mathrm{L}$.

All the components of reaction mixture (including catalyst) were added in the reactor simultaneously. Then at working hydrogen pressure after $80 \mathrm{~min}$ of heating the desired temperature was reached. The samples of liquid phase were periodically taken via valve 15 and analyzed using GC-MS (GCMS-QP2010S). It is noteworthy that he samples of gaseous phase were also taken (via valve 13) and analyzed to provide hypothesis of possible reaction path. To analyze the composition of gaseous mixture the unique analytic complex on the base of GC developed by Tver Technical University was used. The analytic complex consists of two gas chromatographs: Kristallucs 4000M to analyze hydrocarbons concentration, Gasochrom 2000 to determine concentration of $\mathrm{H}_{2}, \mathrm{CO}, \mathrm{CO}_{2}$ and $\mathrm{N}_{2}$. 


\subsection{Catalyst Characterization}

The specific surface area, pore size distribution of the Pd-containing catalysts were investigated by physical adsorption of nitrogen using BECMAN COULTERTM SA 3100TM (Coulter Corporation, Miami, Florida), BECMAN COULTERTM SA-PREPTM (Coulter Corporation, Miami, Florida), and electronic balance GX-200 (A\&D Company, Limited, Tokyo, Japan). The following analysis conditions were used: $\mathrm{t}=-196{ }^{\circ} \mathrm{C}$, relative pressure 0.9814 (for the pores less than $100 \mathrm{~nm}$ ), PSD (ADS) profile.

X-Ray photoelectron spectroscopy (XPS) was carried out using $\mathrm{Mg} \mathrm{Ka}(h v=1253.6 \mathrm{eV})$ radiation with ES-2403 spectrometer (provided by the Institute for Analytic Instrumentation of the Russian Academy of Sciences, St. Petersburg, Russia) equipped with energy analyzer PHOIBOS 100-MCD5 (SPECS, Germany). All the data were acquired at X-ray power of 100 W. The survey spectra were recorded at a step of $0.5 \mathrm{eV}$ with analyzer pass energy $40 \mathrm{eV}$, and high resolution spectra were recorded at a step of $0.05 \mathrm{eV}$ with analyzer pass energy $7 \mathrm{eV}$. The samples were allowed to outgas for $60 \mathrm{~min}$ before the analysis and were sufficiently stable during the examination.

\section{Results and Discussion}

\subsection{Characterization of $\mathrm{Pd} / \mathrm{C}$ Catalysts}

Figure 2 shows the $\mathrm{N}_{2}$ adsorption - desorption isotherms for the $\mathrm{Pd}$ catalysts used in this work. It can be seen from Figure 2 that the isotherms of Pd catalysts are of type IV with a H3 hysteresis loop. It indicates to mesoporous structure having slit-shaped pores [13-14]. Pore size distribution (Figure 3) demonstrates a mean pore size of around $4.5 \mathrm{~nm}$. It should be

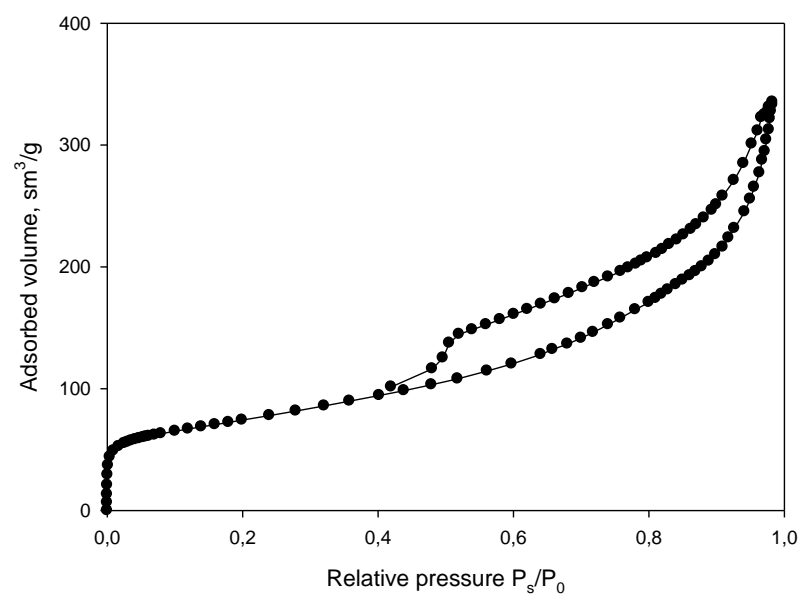

noted difference of surface area for the catalyst $1 \%-\mathrm{Pd} / \mathrm{C}$ it is value $775.0 \mathrm{~m}^{2} / \mathrm{g}$, and for the catalyst $5 \%-\mathrm{Pd} / \mathrm{C}-263.0 \mathrm{~m}^{2} / \mathrm{g}$.

To determine the qualitative and quantitative composition of the surface of Pd-containing catalysts, the study of the samples was performed by the method of X-ray photoelectron spectroscopy. Figure 4 shows the survey spectrum $(\mathrm{a}, \mathrm{b})$ and high resolution spectrum of $\mathrm{Pd}$ $3 \mathrm{~d}_{5 / 2}$ of $1 \%-\mathrm{Pd} / \mathrm{C}$ and $5 \%-\mathrm{Pd} / \mathrm{C}$.

XPS analysis showed that all as-synthesized Pd-catalysts contain palladium, carbon, oxygen, and chlorine on the surface. In Table 2 XPS data on qualitative and quantitative composition (atom \%) of the surface of Pd-catalysts are presented. Value of binding energy of $\mathrm{Pd} 3 \mathrm{~d}_{5 / 2}$ for $1 \%-\mathrm{Pd} / \mathrm{C}$ was shown to be $337.0 \pm 0.1 \mathrm{eV}$, which corresponds to the Pd(II) [15-17]. It was estab-

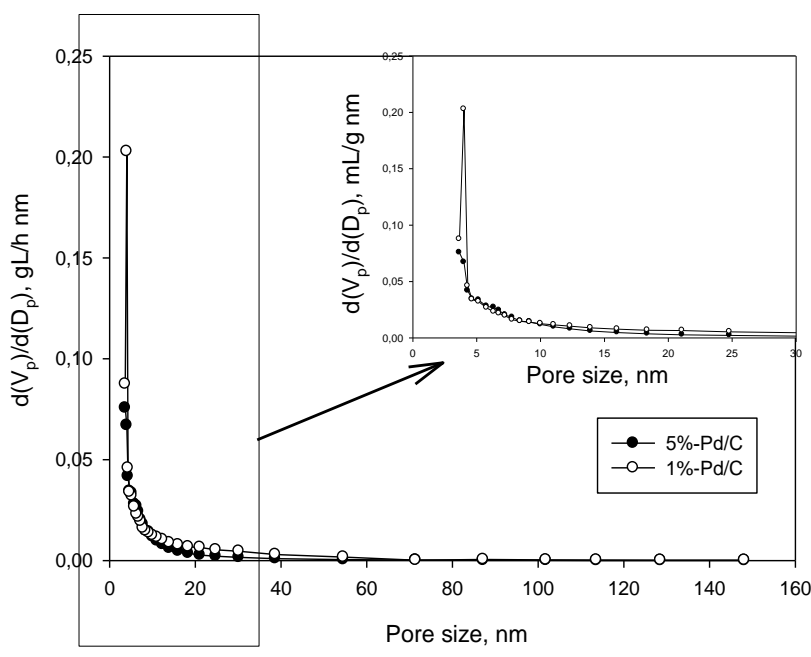

Figure 3. Pore size distribution for the Pd catalysts

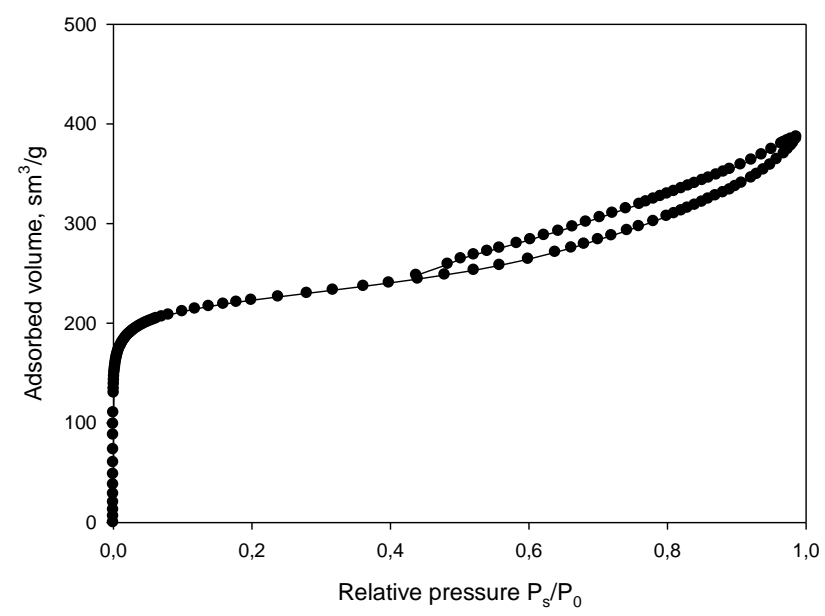

Figure 2. $\mathrm{N}_{2}$ adsorption - desorption isotherms for the Pd catalyst: (a) $1 \%$-Pd/C and (b) $5 \%$ - $\mathrm{Pd} / \mathrm{C}$ 
Table 2. Qualitative and quantitative composition of the surface of Pd-catalysts, according to XPS data and the bond energy for $\mathrm{Pd} 3 \mathrm{~d}_{5 / 2}$

\begin{tabular}{ccc}
\hline & \multicolumn{2}{c}{$\begin{array}{c}\text { Fraction of Pd species } \\
\text { (atom\%)/(bond energy for Pd } \\
3 d 5 / 2, \text { eV) }\end{array}$} \\
\cline { 2 - 3 } & \multicolumn{2}{c}{$\begin{array}{c}1 \%-\mathrm{Pd} / \mathrm{C} \\
5 \text { species }\end{array}$} \\
\hline $\operatorname{Pd}(0)$ & - & $41.8 /(335.0)$ \\
$\operatorname{Pdn}(1<\mathrm{n}<4)$ & $100 /(337.0)$ & $18.5 /(337.4)$ \\
$\operatorname{Pdn}(9<\mathrm{n}<13)$ & - & $39.7 /(336.4)$ \\
\hline
\end{tabular}
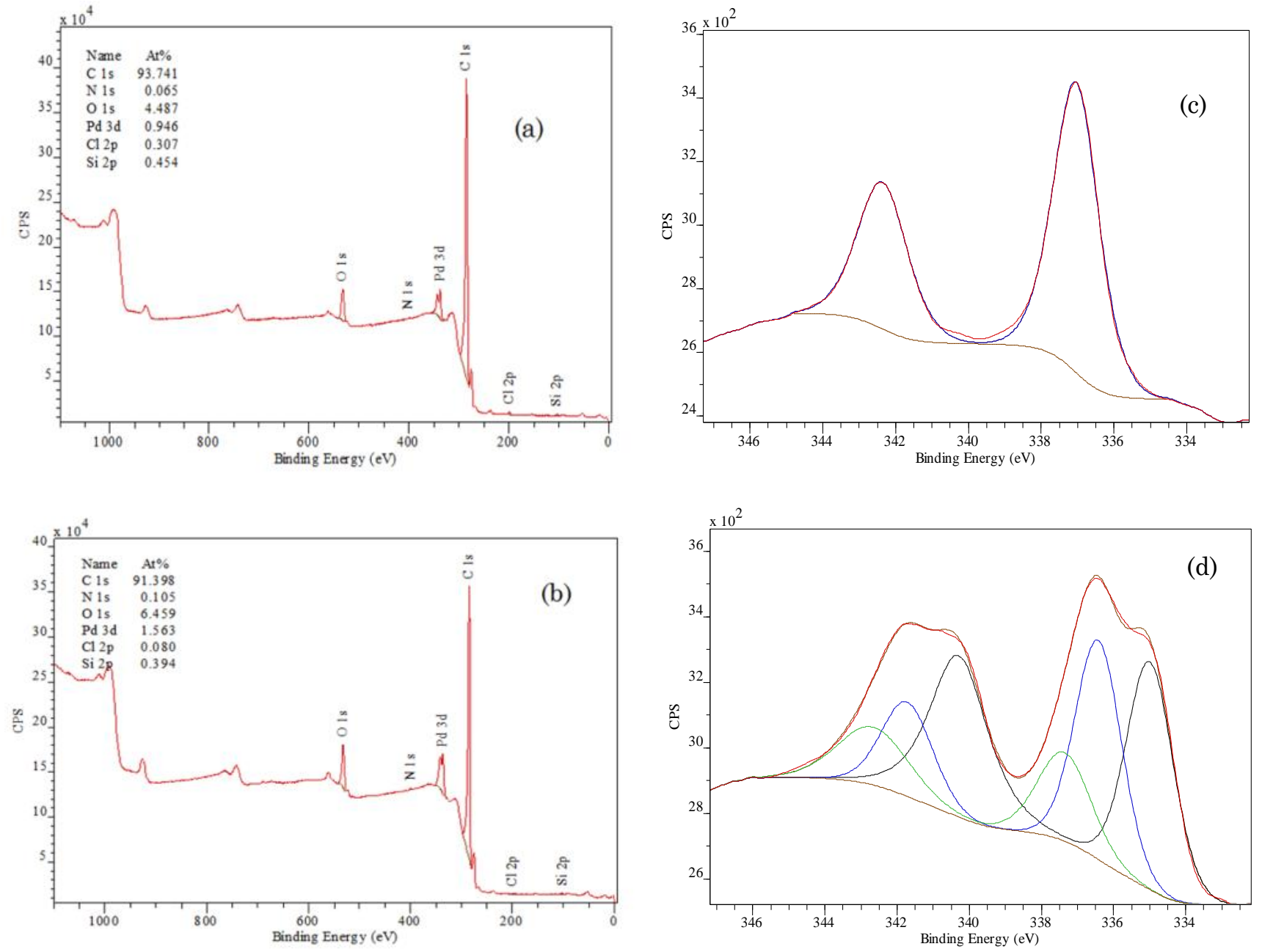

Figure 4. Survey spectrum (a, b) and high resolution spectrum of $\mathrm{Pd} 3 \mathrm{~d}_{5 / 2}(\mathrm{c}, \mathrm{d})$ for $1 \%-\mathrm{Pd} / \mathrm{C}(\mathrm{a}, \mathrm{c})$ and $5 \%-\mathrm{Pd} / \mathrm{C}(\mathrm{b}, \mathrm{d})$ 


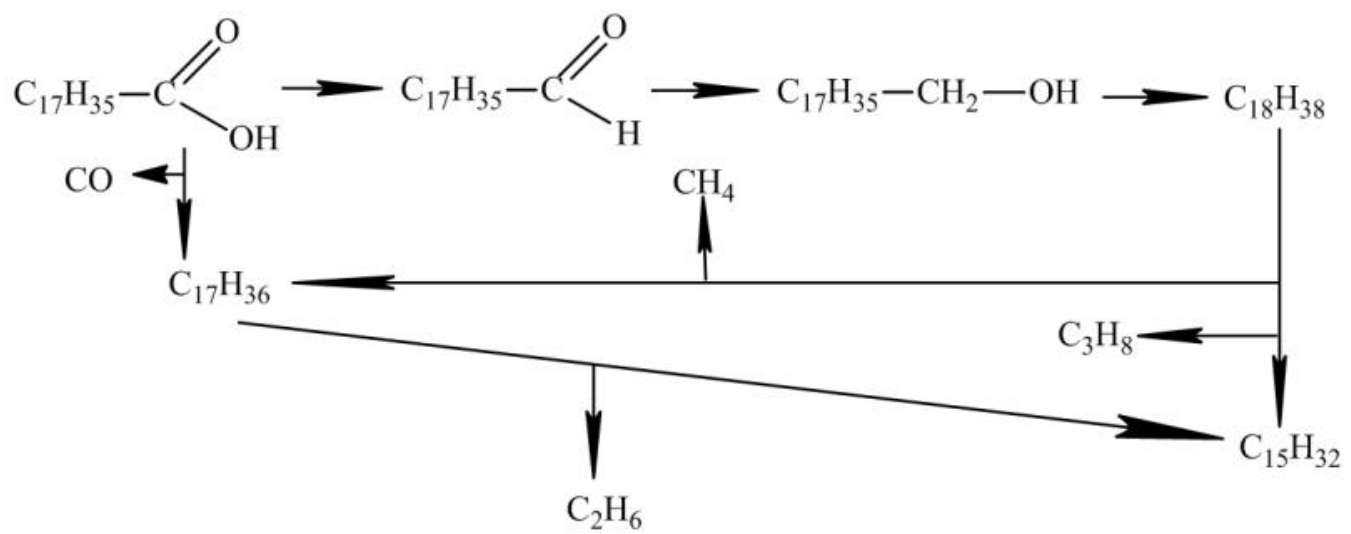

Figure 6. The scheme of reaction product formation

lished according to the analysis results (Table 2) that palladium on the surface $5 \%-\mathrm{Pd} / \mathrm{C}$ is in the form of the mixture of $\operatorname{Pd}(0), \operatorname{Pd}(\mathrm{II})$ in difference from the catalyst $1 \%-\mathrm{Pd} / \mathrm{C}$.

\subsection{Catalytic Testing}

The catalytic properties of the palladium catalysts used in this work in stearic acid hydrodeoxygenation were tested. Conditions of hydrodeoxygenation reaction were the following: temperature $-255^{\circ} \mathrm{C}$, pressure $0.6 \mathrm{MPa}$, stirring rate $700 \mathrm{rpm}$, stearic acid concentration $0.1 \mathrm{~mol} / \mathrm{L}$, catalysts concentration $3 \cdot 10^{-4}$ $\mathrm{mol} \mathrm{Pd} / \mathrm{L}$. In the case of stearic acid hydrodeoxygenation the significant formation of main product ( $n$-heptadecane) was observed. Figure 5 shows the dependences of concentration of stearic acid, heptadecane and pentadecane on reaction time for palladium catalysts. At $100 \%$ of conversion of stearic acid, the selectivity of hydrodeoxygenation was $97.5 \%$ in case of the catalyst $1 \%-\mathrm{Pd} / \mathrm{C}$ and $88.6 \%$ in case of the $5 \%$ $\mathrm{Pd} / \mathrm{C}$. It is visible that increase of the content of palladium in the catalyst leads to decrease in selectivity of process. This fact can be explained by the higher specific surface area of the catalyst with $1 \%$ metal loading, which leads to the availability of $\mathrm{Pd}$ active sites and hence the high activity of this catalyst.

There are several possible mechanisms of fatty acids deoxygenation: decarboxylation, decarbonylation and hydrogenation. While using Pd-containing catalysts, the hydrodeoxygenation process of saturated fatty acids was found to proceed via decarbonylation mechanism. In the case of unsaturated fatty acids two stages take place: (i) hydrogenation of double bonds of unsaturated acids; (ii) decarbonylation of saturated acids with formation of hydrocarbons. To put forward the hypothesis of hydrodeoxygenation mechanism the analysis of gaseous phase
Table 3. The composition of gaseous phase mixture

\begin{tabular}{cc}
\hline Substance & Content, \%(vol.) \\
\hline Methane & 4.89 \\
Ethan & 0.35 \\
Propane & 0.19 \\
Other hydrocarbons & 0.07 \\
CO & 2.30 \\
$\mathrm{H}_{2}$ & 44.07 \\
Air & 11.35 \\
Non identified gases & 36.79 \\
\hline
\end{tabular}

was carried out. The results are shown in Table 3. Thus decarbonylation was found to be the most possible mechanism of the catalytic process due to the presence of $\mathrm{CO}$ in gaseous mixture. Besides, the formation of lowmolecular weight hydrocarbons shows that the cracking also takes place. Basing on the XPS data it can be concluded that the active sites of $1 \%-\mathrm{Pd} / \mathrm{C}$ catalyst are presented by $\mathrm{Pd}$ (II) particles which are more stable and do not deactivate in $\mathrm{CO}$ presence.

While analyzing the experimental data we assumed that possible way of reaction product formation for liquid and gaseous phases: at the beginning the reduction of carboxyl groups to carbonyl ones takes place, then the latter is reduced into alcohol group, and finally the formation of $n$-octadecane is occurred (Figure 6). At the same time the indirect decarbonylation reaction also takes place. Octadecane in turn can be destructed to $n$-pentadecane and $n$ heptadecane. Besides, $n$-pentadecane can be formed as a result of $n$-heptadecane cracking. 
Thus the formation of low molecular weight hydrocarbons (see Table 3) is likely due to the destruction of both octadecane and heptadecane. The obtained data are experimental base for carrying out researches with use of catalysts on the basis of the nanostructured matrixes.

\section{Conclusions}

According to low-temperature nitrogen physical adsorption it was found to be the difference in surface area of the studied catalysts at similar pore structure. $1 \%-\mathrm{Pd} / \mathrm{C}$ catalyst had the higher specific surface area $\left(775.0 \mathrm{~m}^{2} / \mathrm{g}\right)$ in comparison with $5 \%-\mathrm{Pd} / \mathrm{C}\left(263.0 \mathrm{~m}^{2} / \mathrm{g}\right)$ that strongly affects on it catalytic activity in stearic acid hydrodeoxygenation process. The XPS method noted small difference of composition of the surface of Pd and as a result of their distinction in catalytic properties. It was revealed, that the main product of the hydrodeoxygenation of stearic acid was $n$-heptadecane. The selectivity of the process (regarding to $n$ heptadecane) reached up to $97.5 \%$ at $100 \%$ conversion of substrate in the case of the catalyst with $1 \%$ the content of palladium. As a result of investigation the possible paths of transformation of unsaturated acids were proposed. It was found that hydrodeoxygenation process mainly proceeds through decarbonylation reaction with further hydrogenation of obtained unsaturated compounds. Cracking of hydrocarbon products was supposed to occur due to the formation of low-molecular weight gaseous hydrocarbons.

\section{Acknowledgments}

Financial support was provided by the Ministry of Education and Science of the Russian Federation and Russian Foundation for Basic Research.

\section{References}

[1] Kalnes., T., Marker, T., Shonnard, D.R. (2007). Green diesel: a second generation biofuels. International Journal of Chemical Reactor Engineering, 5: 748-750.

[2] Sooknoi, T., Danuthai, T., Lobban, L.L., Mallinson, R.G., Resasco, D.E. (2008). Deoxygenation of Methyl Esters over CsNaX. Journal of Catalysis, 258: 199-200.

[3] Snäre, M., Kubičkova, I., Mäki-Arvela, P., Eränen, K., Murzin, D.Yu. (2006). Heterogeneous Catalytic Deoxygenation of Stearic Acid for Production of Biodiese. Industrial \& Engineering Chemistry Research, 45(16): 57085719 .
[4] Li, L., Coppola, E., Rine, J., Miller, J.L., Walker, D. (2010). Catalytic hydrothermal conversion of triglycerides to non-ester biofuels. Energy Fuels, 24: 1305-1315.

[5] Holmgren, J., Gosling, C., Couch, K., Kalnes, T., Marker, T., McCall, M., Marinangeli, R. (2007). Biorenewable integration in refineries is evaluated along with work to commercially produce green diesel. Petroleum Technology Quarterly, 3: 119-125.

[6] Immer, J.G., Lamb, H.H. (2010). Fed - Batch Catalytic Deoxygenation of Free Fatty Acids. Energy \& Fuels, 24: 5291-5299.

[7] Morgan, T., Grubb, D., Santillan-Jimenez, E., Crocker, M. (2010). Conversion of triglycerides to hydrocarbons over supported metal catalysts. Topics in Catalysis, 53: 820829.

[8] Do, Ph.T., Chiappero, M., Lobban, L.L., Resasco, D.E. (2009). Catalytic Deoxygenation of Methyl-Octanoate and Methyl-Stearate on $\mathrm{Pt} / \mathrm{Al}_{2} \mathrm{O}_{3}$. Catalysis Letters, 130: 9-18.

[9] Rar, M., Kovacs, S., Kallo, D., Hancsok, J. (2010). Fuel Purpose Hydrotreating of Sunflower Oil on $\mathrm{CoMo} / \mathrm{Al}_{2} \mathrm{O}_{3}$ Catalyst. Bioresourse Technology, 101: 9287-9293.

[10] Hoang, T.Q., Zhu, X., Danuthai, T., Lobban L.L., Resasco, D.E., Mallinson, R.G. (2010). Conversion of Glycerol to Alkyl-aromatics over Zeolites. Energy Fuels. 24: 3804-3809.

[11] Danuthai, T., Jongpatiwut, S., Rirksomboon, Th., Osuwan, S., Resasco, D.E. (2009). Conversion of methylesters to hydrocarbons over an H-ZSM5 zeolite catalyst. Applied Catalysis A: General, 361: 99-105.

[12] Dundich, V.O., Khromova, S.A., Ermakov, D.Yu., Lebedev, M.Yu., Novopashina, V.M., Sister, V.G., Yakimchuk, A.I., Yakovlev, V.A. (2010). Nickel catalysts for the hydrodeoxygenation of biodiesel. Kinetics and Catalysis, 51(5): 704-709.

[13] Gregg, S. J., Sing, Kenneth S.W. (1982). Adsorption, Surface Area, \& Porosity, Second Edition. Hardcover.

[14] Donohue, M. (2010). A New Classification of Adsorption Isotherms. Citing Internet $\begin{array}{llllllllllllll}s & o & u & r & c & e & s & \mathrm{U} & \mathrm{R} & \mathrm{L}\end{array}$ http://www.nigelworks.com/mdd/.../NewClas s.pdf

[15] NIST X-ray Photoelectron Spectroscopy Database, Version 3.5. (National Institute of Standards and Technology, Gaithersburg, 2003). Citing Internet sources URL http://srdata.nist.gov/xps/ 
[16] Wu, T., Kaden, W.E., Kunkel, W.A., Anderson, S.L. (2009). Size-dependent oxidation of $\mathrm{Pd}_{\mathrm{n}}(\mathrm{n} \leq 13)$ on alumina/NiAl(110): Correlation with Pd core level binding energies. Surface Science, 603: 2764-2770.
[17] Penner, S., Bera, P., Pedersen, S., Ngo, L.T, Harris, J.J.W., Charles, T. (2006). Campbell. Interactions of $\mathrm{O}_{2}$ with $\mathrm{Pd}$ Nanoparticles on a- $\mathrm{Al}_{2} \mathrm{O}_{3}(0001)$ at Low and High $\mathrm{O}_{2}$ Pressures. Journal of Physical Chemistry B, 110: 24577-24584. 